\title{
"Nobody Knows What Is in Them until They Are Broke up": Medbh McGuckian's Feminist Poetry
}

\section{Shane Alcobia-Murphy}

\section{(2) OpenEdition}

\section{Journals}

Electronic version

URL: https://journals.openedition.org/etudesirlandaises/3183

DOI: 10.4000/etudesirlandaises.3183

ISSN: 2259-8863

\section{Publisher}

Presses universitaires de Caen

Printed version

Date of publication: 30 October 2012

Number of pages: $97-111$

ISBN: 978-7535-2158-2

ISSN: 0183-973X

Electronic reference

Shane Alcobia-Murphy, "'Nobody Knows What Is in Them until They Are Broke up": Medbh

McGuckian's Feminist Poetry", Etudes irlandaises [Online], 37-2 | 2012, Online since 30 October 2014, connection on 27 July 2022. URL: http://journals.openedition.org/etudesirlandaises/3183 ; DOI: https://doi.org/10.4000/etudesirlandaises.3183

This text was automatically generated on 27 July 2022

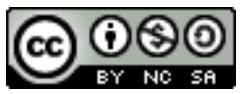

Creative Commons - Attribution-NonCommercial-ShareAlike 4.0 International - CC BY-NC-SA 4.0 https://creativecommons.org/licenses/by-nc-sa/4.0/ 


\title{
"Nobody Knows What Is in Them until They Are Broke up": Medbh McGuckian's Feminist Poetry
}

\author{
Shane Alcobia-Murphy
}

1 In a recent article, María Jesús Lorenzo-Modia and Cristina Fernández-Méndez contend that, although Medbh McGuckian's work "shows certain feminist traits", it ought not to be viewed within the paradigm of feminism for two key reasons: firstly, "the protean nature" of her poetry "prevents it from being assimilated into any pre-existing way of seeing the world"; secondly, answers given by her in interview seem less than radical, upholding instead "the traditional Irish stereotypes for women ${ }^{1}$ ". In many respects the authors' findings do not differ from those of Anne Fogarty's critically astute article "A Noise of Myth" from 1994 in which she articulates the seeming discrepancy between McGuckian's poetic voice, one that seeks "an accommodating space for female experience and language", and her public persona, which appears utterly antithetical to the feminist movement ${ }^{2}$. Indeed, their reading of her work within a Kristevan theoretical framework, emphasizing its pluralist and non-essentialist nature, is a strategy which is much in vogue since it allows critics a methodology to appreciate, and write about, a poetry that is so self-reflexive about its own production ${ }^{3}$. Yet it seems odd to deny the poetry's feminist aspects which have been widely acknowledged, certainly since Clair Wills' seminal study, Improprieties, in which she convincingly showed how McGuckian opposes the overbearing Catholic and nationalist ideals of femininity with a poetry that foregrounds "the bodily and corporeal nature of the meanings of motherhood ${ }^{4 "}$.

2 Looking at the arguments put forward by Lorenzo-Modia and Fernández-Méndez, their first objection for viewing McGuckian as a feminist can be easily dismissed since describing a poet's work as "feminist" does not necessarily restrict her worldview to a single ideology. However, there is some compelling evidence to support their second objection. McGuckian, in conversation with Susan Shaw Sailer, stated that "I find feminism attractive in theory but in practice I think it ends up influenced by lesbians 
and - very lonely and embittered and stressed and full of hatred ${ }^{5 "}$. Such a reductive (and potentially offensive) generalisation certainly suggests that she had, at the time of the interview at least, little affinity with the work done by feminist practitioners and/ or theorists. However, it is unwise to dismiss a poet's feminist credentials on the basis of selective quotation from interviews since their contexts differ and the answers can vary from one moment to the next. A year later, when interviewed by Kimberly S. Bohman, the poet is discernibly less antagonistic. Asked if she regarded herself as a feminist, she offered a mea culpa: "To me I failed as a feminist once I got married. It seems to me that if you were wearing a ring on your finger then you're chained to male society and you've accepted that. You've accepted their mores." While Lorenzo-Modia and Fernández-Méndez cite this response in their article, they fail to acknowledge her immediate corrective: “Well, I didn't see it as a failure. I just felt that I was a weak person. I felt I had to belong to somebody, or felt that in order to be free in the poetry, I had to be tied in the life ${ }^{7}$." What McGuckian actually puts forward here is a reflective self-critique, one which displays an awareness of the power differentials inherent in matrimony and does not intimate a current stance inimical to feminism. Indeed, far from being "unable and unwilling to distance herself from her Northern Irish Catholic community" in terms of her views on gender ${ }^{8}$, the poet in the same interview criticises misogynistic Catholic ideology: "I believe that sin is something that the church has given us - women especially - an idea that their bodies are in themselves evil ${ }^{9}$." In this article I want to argue that McGuckian's oeuvre is profoundly concerned with matters of female identity in ways that mark it out as feminist. Her historical gaze lays bare the essentialist, gendered rhetoric used within patriarchal culture which renders women as marginal, submissive and disempowered. In poems which borrow from texts as diverse as source books on women's culture in Renaissance Italy and sociological studies of women's housework, McGuckian investigates the sources of male power, explores how women's bodies are viewed and defined throughout the ages. Using and altering the words of others, she is never complicit in the practice of "othering"; rather, each of McGuckian's poems can be viewed as a palimpsest, a means of "writing in the interstices of texts, boring thru the white between the lines, scribbling on the margins ${ }^{10 "}$.

3 In "The Character of the Dug Explained", McGuckian employs as her source text Will Pritchard's Outward Appearances, a study which ranges across the literature, legal reports, conduct books and anatomical treatises of the Restoration period in its exploration of how men perceived female display ${ }^{11}$. Pritchard argues that women of the time were under a contradictory imperative: "keep yourselves private, so as to remain modest, and make yourself public, so that your modesty may be proved and approved" (OA 63). While display was thus both encouraged and stigmatized in equal measure, a woman's moral well-being was said to be inscribed on her body; exterior features were read to determine "the truth of her social and spiritual identity" (OA 15). The contemporary debate concerned the notion of an "authentic" identity. Was character essentially a matter of birth and breeding, or could it be acquired? Could that character be discerned accurately from a woman's appearance? If character is to be determined according to behavioural traits and physical appearance, is it not subject to manipulation and dissemblance? The poem's title alludes to these matters: while "character" refers to the aggregate of the breast's distinctive features, the word also means "the sum of moral and mental qualities"; the latter is supposed to be revealed through the former. What interests both Pritchard and McGuckian is the gendered 
rhetoric surrounding such issues of female legibility. The opening stanza depicts a Cartesian mindset whereby the rational faculty is separate from, and has priority over, the body:

Philosophy I say and call it he, my throat hurts

From all the j's and h's: a woman and a melon

Are both alike, nobody knows what is in them

Until they are broke up. It is as impossible

To dive into the heart of a woman as to run

Your head, body and all into her fundament.

Here, "philosophy" is properly the remit of men who objectify and seek free access to, and control of, the (female) body. The opening line adopts the rhetoric of the time: as Pritchard argues (citing from Abraham Cowley's poem "To the Royal Society"), "[i]n writings from the period, probing science was repeatedly cast as male ('Philosophy, I say, and call it, He. / For what-so'ere the Painters Fancy be, / It a Male-virtue seemes to me'), and fleeing nature was female" (OA 65). While scientific advances in anatomy held out the promise that female legibility was attainable, the stanza incorporates the obverse fear of inscrutability. "Woman" and "melon" are equivalent in the sense that they must be penetrated and broken up in order to be rendered fathomable. As Pritchard states,

"Women's actions are like their wombs, not to be fathomed", was one adage; another

was "A woman and a melon are both alike. For till they are broke up, nobody knows

what is in them". But when authors made claims such as "it is impossible to dive into into the Heart of a Woman, as it is to run your Head, Body and all into her

Fundament", they were implying that full carnal knowledge of a woman was

equivalent to knowledge of her innermost self. The very impossibility of fathoming

a

woman's womb, breaking her open like a melon or entering entirely into her

"Fundament" (anus), reinforced the sense that the female body contained the secrets

of women's hearts and actions. (OA, 67, original italics)

Viewing a woman as naturally "other" meant that her body "must be subjected to constant surveillance ${ }^{12}$ ", yet patriarchal control falters here: the inability to fully discern a woman's nobility and moral probity leads to the fear that she is inscrutable and ultimately unknowable. To render the female body transparent and wholly legible, the poem's addressee turns to the discipline of anatomy:

\begin{tabular}{|c|c|}
\hline $\begin{array}{l}\text { "Y" have taught the curious Sight to press / Into the } \\
\text { privatest recess / Of her imperceptible littleness" } \\
\text { (OA 67); } \\
\text { Sweet-bread [...] Piss-bladder [..] Arse-gut [...] Flank- } \\
\text { bone (OA 69); The parts which in Women serve for } \\
\text { generation (OA 69); The descendent Trunk of Vena } \\
\text { cava } \\
\text { with its Branchings (OA 69); The Trumpets of the } \\
\text { seed (OA 69); resembling the Wings of Bats or Flitter } \\
\text { mice (OA 69); The greatest and middlemost } \\
\text { Kernel (OA 69); }\end{array}$ & $\begin{array}{l}\text { You have taught the curious sight to press } \\
\text { Into the privatest recess of her littleness } \\
\text { Her sweet-bread, piss-bladder, arse-gut } \\
\text { Flank-bone, the parts which in women serve } \\
\text { For generation, the descendant trunk } \\
\text { of Vera Cava with its branching } \\
\text { The trumpets of the womb or blind passage } \\
\text { of the seeds, resembling the wings of bats } \\
\text { Or flittermice, the greatest and middlemost } \\
\text { kernel }\end{array}$ \\
\hline
\end{tabular}


In the stanza's opening lines, McGuckian cites Cowley's encomium to the medical profession which praises the Royal Society for its ability to peer into the depths of the female body. She then uses the corporeal descriptors from a medical diagram in Bartholinus Anatomy (cited by Pritchard) that outlines "the parts which in Women serve for Generation" (OA 69) in order to "dissect" her subject. Of course, "dissection" has a double meaning: on the one hand, it refers to "the delicate separation of constituent structures"; on the other, it can be viewed as "a more violent 'reduction' into parts ${ }^{13}$ ". Dissective culture demands that the once complete body must be opened up and fragmented to form a new body of understanding ${ }^{14}$. McGuckian's description, breaking down one section of the body into its constituent parts, is no less grotesque than Shakespeare's anatomisation of the female subject in Sonnet 130, wherein the loved one is reduced to "eyes", "breasts", "lips", and "cheeks", but the later poem more overtly lays bare the violence associated with the male appropriative gaze and therein lies an implicit critique of the period's treatment of women as objectified, marginal beings who were subject to male prohibitions.

7 Cultural studies of the Renaissance and beyond demonstrate that the "female body [...] was the locus of a quite specifically gender-determined fear ${ }^{15}$ ", namely an anxiety associated with female viscera, specifically the areas associated with generation and parturition. As Katharine Park has shown, in anatomical studies there was a "disproportionate emphasis on the uterus relative to the other members of the human body" because it was "mysterious" and "difficult to understand ${ }^{16 "}$ ". In contrast to woodcuts of the dissected female figure in the Fasiculo de medicina (1494) which portray her as instructing the anatomist, thus implicitly having voice and authority despite being the object of scrutiny, the autoptic vision is reversed in Bartholinus: while we are presented with an unimpeded view of the genitals, female agency is displaced to the surrounding captions. The descriptive terms serve less to idealise than to excoriate the female body: "piss-bladder" and "arse-gut" reveal a fundamental baseness, "sweetbread" indicates availability for consumption, and "littleness" betrays the woman's unequal social standing. In McGuckian's poem, the display of female viscera is not done for the purpose of teaching anatomy to medical practitioners but merely to allay the addressee's fear arising from withheld access. Yet full visibility is not granted: the Fallopian tubes are described as "the blind passage of the seed" (my italics). The following stanza further confirms this inscrutability: 


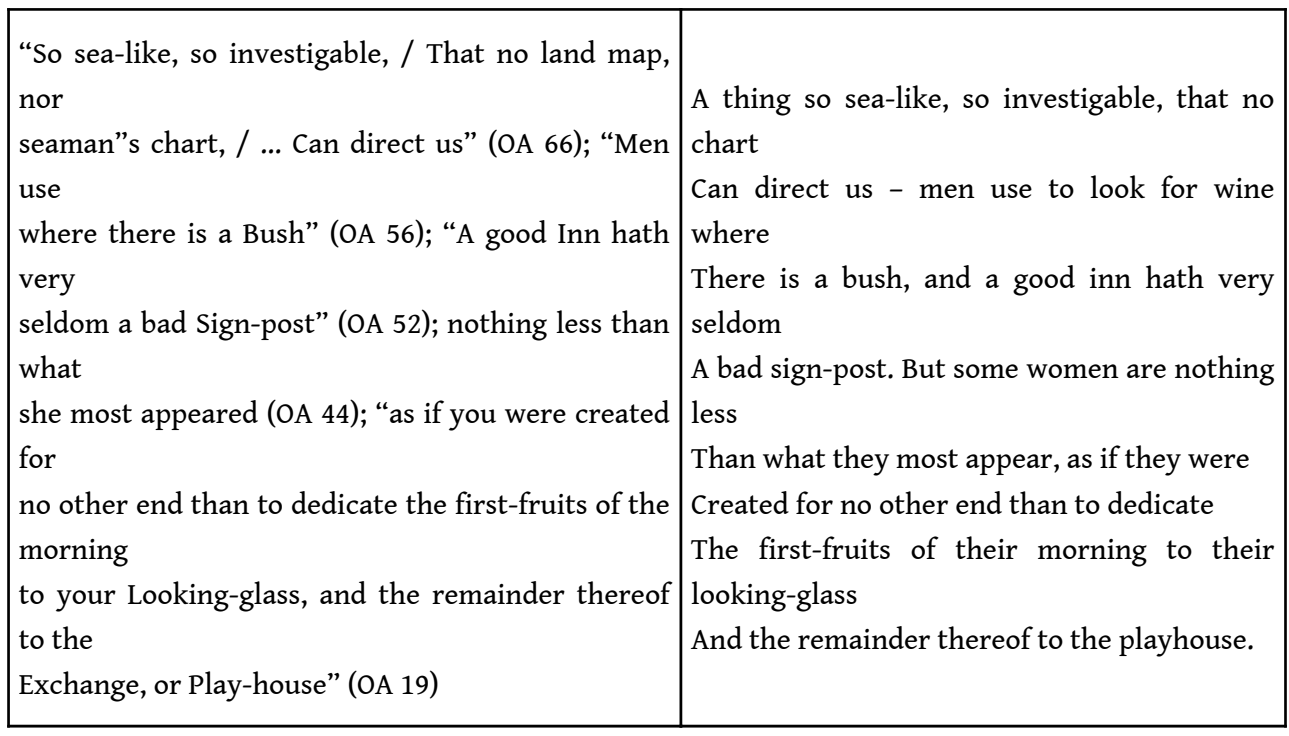

8 The opening quotation, from Charles Cotton's poem "Woman", portrays the objectified female as an irresistible puzzle which is nevertheless resistant to scientific enquiry. The next quotations, from Dorcas Bennet's Good and Seasonable Counsel for Women, from a Woman (1670) and Richard Graham's Angliae Speculum Morale (1670), counsel women to cover up their body. Female attire functions as an index of moral character; in this post-Edenic worldview, nakedness is akin to sinfulness. In the quotations cited by McGuckian, the bodily signs of the neck and breasts function in the manner of a sign above a shop. Hence, there is a presupposed belief in the intrinsic relation between the female subject's interior and exterior disposition. Bodily signs rather than those associated with behaviour were privileged as a means of determining a woman's identity. As Pritchard argues,

First, they were seen as more determinate and indelible, less open to manipulation

or

falsification. Behaviour could be feigned, bodies could not; they did not seem susceptible to self-difference. Second, bodily signs more strongly asserted the importance of birth to identity. They mitigated against the type of relativism and social fluidity that behavioural signs permitted. (OA 52)

Yet such certainty is undermined in McGuckian's poem as she goes on to cite from the story of Mary Carleton, an infamous bigamist and confidence trickster, "who was nothing less than what she most appeared" (OA 44). Arriving at the Exchange Tavern in March 1663, Carleton for a time successfully passed herself off as a German noblewoman; traversing class boundaries, she assumed the role through the manipulation of both costume and behaviour. While a conduct book such as The Gentlewoman's Companion (1675) might advise against behaving "as if you were created for no other end than to dedicate the first-fruits of the morning to your Looking-glass" (OA 19), Carleton gained social status and riches by doing just the opposite. Indeed, in a later stanza McGuckian cites from Jacques Olivier, Discourse of Women (1662) to present the various means by which women triumphed over men through imposture and cunning:

[T] hey have a whole arsenal

Of aspects and idle looks, gaudiness and ceremonies.

They will wanton with their gloves and handkerchiefs. 
10 Female identity, then, is treated throughout McGuckian's poem as being nonessentialist, fluid and theatrical, open to both bodily and behavioural manipulation; it defeats the male gaze, avoids scientific scrutiny and contravenes social prescription. Of course, the form of the text embodies its key thematic concern: by constructing her poem from unattributed quotations, the poet has hidden from our gaze; she has adopted a persona, one whose identity is utterly false and unstable. Her poetic impersonation allows her to co-opt a male Restoration world-view, with its constituent rhetoric, all the while remaining subversively detached from and non-complicit with its ideological presumptions.

11 McGuckian does not restrict her critique of how women are constructed as "patriarchal territories ${ }^{17}$ " to the Restoration period. In "The Good Wife Taught her Daughter", for example, she rewrites the medieval didactic poem of the same name - generically, it was a parental advice text - by splicing together quotations from Sarah Salih's cultural analysis of the conduct literature of the time ${ }^{18}$ :

\begin{tabular}{|l|l|}
\hline $\begin{array}{l}\text { lordship is the same activity whether performed by } \\
\text { lord or lady (MW 128); in which a lord happens } \\
\text { to be a lady (MW 131); "all the faults" (MW 131); }\end{array}$ & $\begin{array}{l}\text { Lordship is the same activity } \\
\text { whether performed by lord or lady } \\
\text { or a lord who happens to be a lady, } \\
\text { all the source and all the faults }\end{array}$ \\
$\begin{array}{l}\text { a woman "stedfast in lokyng" (MW 134); "a } \\
\text { callot" (MW 135); any woman in the wrong } \\
\text { place (MW 125-6); A woman outside of her proper } \\
\text { location is by definition "a foolysshe woman" (MW 126); }\end{array}$ & $\begin{array}{l}\text { A woman steadfast in looking is a callot } \\
\text { and any woman in the wrong place } \\
\text { is, by virtue of that, a foolish woman }\end{array}$ \\
$\begin{array}{l}\text { The harlot [...] is "talkative and wandering, not bearing } \\
\text { to be quiet, not able to abide still at home, now abroad, } \\
\text { now in the streets, now lying in wait near the } \\
\text { corners" (MW 125);" }\end{array}$ & $\begin{array}{l}\text { The harlot is talkative and wandering } \\
\text { by the way, not bearing to be quiet, } \\
\text { not able to abide still at home, } \\
\text { now abroad, now in the streets, }\end{array}$ \\
$\begin{array}{l}\text { "their hair straying out of theirwimples and the } \\
\text { collars of their shifts and robes one upon the } \\
\text { others"(MW 134) }\end{array}$ & $\begin{array}{l}\text { now lying in wait near the corners, } \\
\text { her hair straying out of its wimple. } \\
\text { The collar of her shift and robe } \\
\text { Pressed, one upon the other. }\end{array}$ \\
\end{tabular}

The opening lines' declaration of the apparent equality between the sexes has some basis in fact since the conception of lordship was at times gender-neutral; noblewomen and gentlewomen often took charge of the estates in the absence of their husbands, and their household activities were not always gender-specific. However, given that the poem focuses exclusively on how the behaviour and appearance of women were closely regulated, the statement is soon made to sound hollow. A woman who was not in the right place, who strayed beyond her "proper location" was branded as "foolish". Although the term sounds relatively benign, the specific example, from which the general rule is inferred, relates to Dina, a victim of rape who was deemed to have invited the assault by the mere act of leaving her house. "Foolish", in McGuckian's text, is equated with a second term: "callot" (harlot). In the Ménagier de Paris's treatise on 
good household management practices, a woman who maintains her bodily selfdiscipline, she who is "stedfast in lokying", becomes a symbol of the respectability of her household: she "shalle ye holde you in youre estate more ferme and sure" (MW 134). Yet in McGuckian's poem such a woman is designated as a prostitute. "Steadfast looking" in the original text infers that the woman is dutifully aware of her status in society: downcast eyes indicate social inferiority, while a steady gaze signifies nobility. Advice manuals of the time recommended that women, to preserve their space in the public realm, should "keep their eyes down"; hence, as Barbara Hanawalt argues, "[w]omen's spaces [...] could be effectively preserved by physical limitations of the movement of the head and eyes ${ }^{19}$. . However, McGuckian alters the context and changes the implication of "looking": here, in a sexual context, the woman has a clear determination to "look" (appear) despite strictures to the contrary. Unregulated contact, or even simply being seen at a window, can imply availability and entail symbolic penetration, thus entailing a threat to her chastity (MW 131). Indeed, McGuckian's speaker later cautions against making oneself visible at such a dangerous liminal space by repeating the instruction given by the author of the Ancrene Wisse: "love your windows as little as you can" (MW 33).

Both the source and quoting texts foreground the prescriptions and prohibitions imposed upon medieval women in Europe. As Salih argues, everything associated with women was "legible and significant: dress, gesture, speech, and place all embod[ied] the discipline of which the individual [was] both subject and performer" (MW 136). The regulations which dictated how women were meant to negotiate domestic and social spaces could be found in the conduct literature which worked "to contain women literally, but also to produce women who [had] so interiorized the values of the household that they [would] carry them with them even when elsewhere" (MW 133). A "good woman" had to adopt a demeanour which exemplified "her control over her speech and sexuality, thus defining the nature of her interaction with the outside world" (MW 134). The woman was designated "bad" if she ignored the gender-specific regulations governing her behaviour. Thus, she became a "harlot" if she transgressed the injunctions governing her speech ("not bearing to be quiet"), appearance ("hair straying out of its wimple"), and movement ("not able to abide still at home"). Indeed, these examples conform to Stallybrass's analysis of patriarchal territories: he argues that "the closed mouth" was a sign of chastity, which in turn was "homologous to woman's enclosure within the house ${ }^{20 "}$. McGuckian's poem relates the story of one particular "bad woman":

\begin{tabular}{|l|l|}
\hline $\begin{array}{l}\text { "the said Margery left her home in the parish of } \\
\text { Bishopshill and went to a house, the which this }\end{array}$ & $\begin{array}{l}\text { The said Margery left her home } \\
\text { in the parish of Bishopshill, }\end{array}$ \\
$\begin{array}{l}\text { witness does not remember, in the city of York without } \\
\text { and contrary to the said Thomas, her husband [...] and } \\
\text { stayed there from noon of that day until the darkness of } \\
\text { night" (MW 126) }\end{array}$ & $\begin{array}{l}\text { and went to a house, the which } \\
\text { the witness "does not remember", } \\
\text { and stayed there from noon } \\
\text { of that day until the darkness of night. }\end{array}$ \\
\hline
\end{tabular}

14 Margery Kempe had petitioned for a separation from her husband, Thomas, on the grounds of cruelty; however, his violence was deemed acceptable by the court because 
of "her refusal to stay within the household" (MW 126). Hence, given the inherent gender inequalities of medieval prescribed social protocols and legal codes, in this poem "Lordship" is clearly not "the same activity / whether performed by lord or lady".

The late medieval poem, "The Good Wife Taught her Daughter", an exhortative text in which a mother figure both counsels and admonishes her female offspring in order to inculcate the dominant social values, does not envisage a society in which a woman must be wholly confined to the domestic space, and does assume "that a housewife will routinely sell goods in the market place" (MW 125). However, the speaker in McGuckian's poem voices a contrary, more prescriptive view:

\begin{tabular}{|l|l|}
\hline $\begin{array}{l}\text { "he should neuer haue my good wyll for to make my } \\
\text { to selle kandyll and mustard in Framlyngham" (MW 125); } \\
\begin{array}{l}\text { a shopping list of crossbows, almonds, sugar, and } \\
\text { cloth (MW 129) }\end{array}\end{array}$ & $\begin{array}{l}\text { He should never have my good will } \\
\text { for to make my sister for to sell } \\
\text { candle and mustard in Framlyngham, } \\
\text { or fill her shopping list with crossbows, }\end{array}$ \\
& almonds, sugar cloth. \\
\hline
\end{tabular}

Comparing the source text with McGuckian's poem, it is possible to argue that she is making a correct distinction between the ways in which space is controlled for upper and lower class women; as Salih states, "[e]ntirely proper wifely behaviour in the one case is a shocking breach of class status in another" (MW 125). Yet perhaps the real reason why McGuckian takes a more caustic view is due to the research that she has done while composing her historically based poems: the essays, monographs and conduct books that she has consulted consistently depict women as being subject to male surveillance, self-censorship and curtailed movement in society.

"The Good Housewife", for example, is based on a sourcebook edited by Mary Rogers and Paola Tinagli containing extracts from diaries, conduct books, legal documents, inventories, letters, treatises, and poetry, each of which presents burdensome instructions for and idealised portraits of Italian women during the Renaissance. The following is taken wholesale from the advice presented in a letter from Francesco Datini to his wife, Margherita ${ }^{21}$ : 


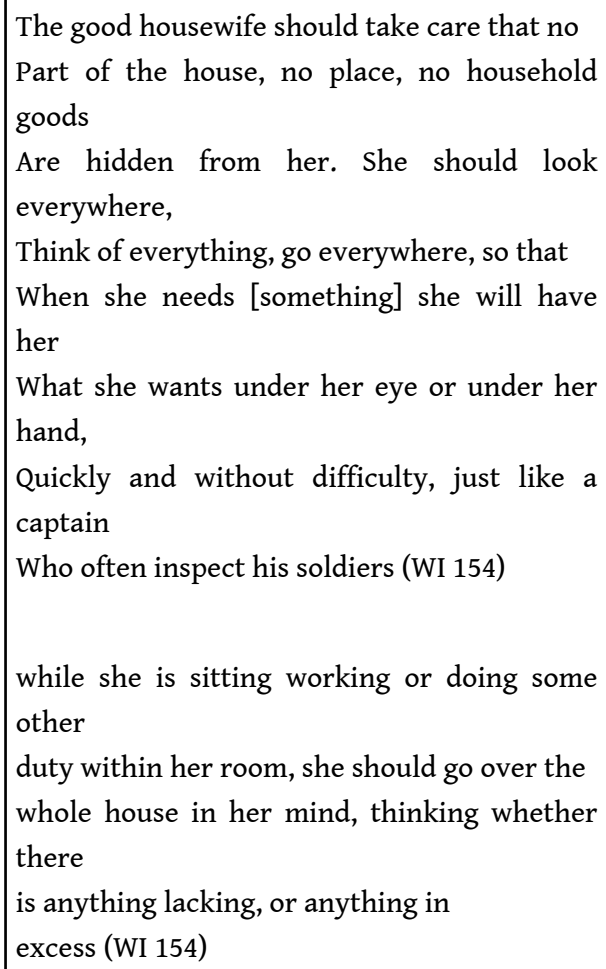

The good housewife should take care that no

Part of the house, no place, no household goods Are hidden from her. She should look everywhere, Think of everything, go everywhere, so that When she needs something she will have what she wants

Under her eye, or under her hand, quicly, And without difficulty, like a captain who often Inspect his soldiers.

while she is sitting working or doing some other duty within her room, she should go over the whole house in her mind, thinking whether there is anything lacking, or anything in excess

The wife's identity, her personality and character traits, are nullified by, or at least subsumed under, the general epithet, "good housewife", a designation which is far from neutral in meaning: the adjective conjoins occupational proficiency with moral probity, the former determining the latter. The husband's letter constitutes a "found poem" for McGuckian, and her rendition of it from prose into poetry calls attention to its more malign features. The first line break calls our attention to the threatening aspect of his instruction: the line now reads as a stern warning rather than as a spousal entreaty. The wife is urged to "look everywhere", to "think of everything" and to "go everywhere": such imperatives may at first suggest freedom (of movement and of access), yet they are, strictly speaking, impossible to carry out. The scopic regime depicted in the text seems to suggest that all the power resides with the wife: she is the overseer who shall ensure that nothing is "hidden from her", and she is like the "captain" who "often / inspects his troops". However, the personal pronoun used here, and the fact that the husband employs a simile, implies that only a man can inhabit such a role ("his troops"). Thus, the section title given for this letter in the sourcebook "A wife rules over the household" - is now rendered wholly ironic by its poetic treatment. It is clear that the husband is the overseer and she is merely one of his troops. Indeed, the line break at the start of the second verse calls attention to the wife's subordinate role since it emphasises her "duty".

One could contend that the entirely negative view of "wifely" and "motherly" duties, and the restrictions under which the women must live, stems from her more contemporary concerns regarding the status of the housewife. In fact, it is clear that the theme has been a major preoccupation throughout her writing career. There are very many early poems by McGuckian which are based on feminist critiques of a wife's status in society and her work in the home. One untitled (and unpublished) text takes 
as its source Ann Oakley's Woman's Work, a sociological study of women's status in preand post-industrialised Western society, and Patricia Morgan's Child Care: Sense and Fable, a rejoinder to the Maternal Deprivation Theory which argued that unbroken child care was essential to the development of one's offspring ${ }^{22}$ :

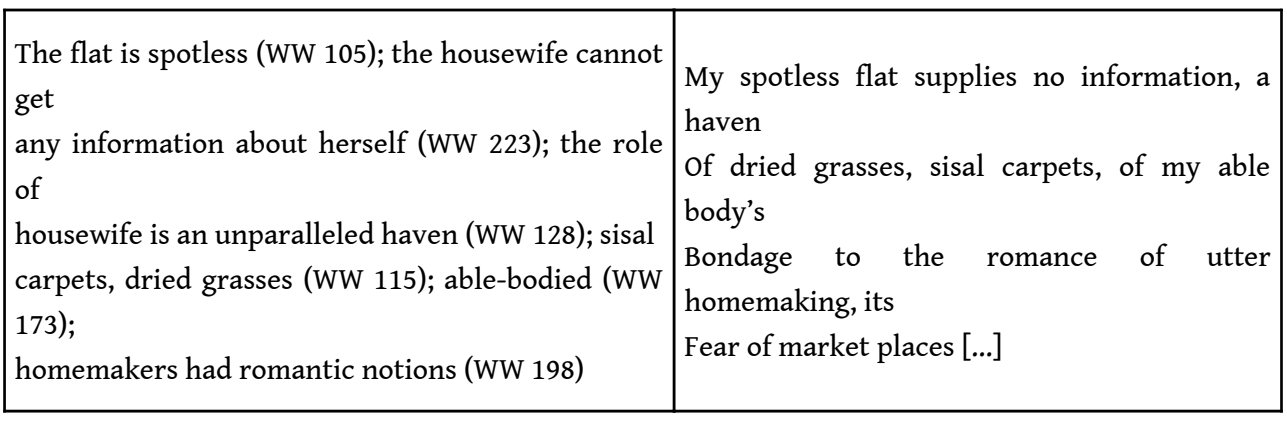

The poem's opening is entirely ironic: although it seems to be a statement of secure proprietorship, a declaration of implicit pride about her domicile's pristine condition, and an acknowledgement that nothing is revealed therein, the opposite is the case. Her self-reflexive comments acknowledge that she is aware of how she has become entrapped by her menial, economically dependent occupation as a housewife and, consequently, has been isolated from society ("fear of marketplaces"). In her study, Oakley cites Alice Rossi's survey of American female college graduates (1961) which concluded that "'[i]t is almost as though home-makers had romantic notions concerning marriage and family roles which the reality of marriage and motherhood tempers... Marriage and family roles are less fully satisfying to the home-makers than they expected them to be"' (WW 198). Since McGuckian quotes from this passage, the speaker's opening remarks imply that the she has become equally disillusioned. While "haven" connotes a place of safety and refuge, a welcome retreat from a threatening or unforgiving world, it has been argued that housewives, due to gender-role conditioning, have come to embrace their "vocation" as "an unparalleled haven" out of psychological necessity, and view it as an index of femininity (WW 128). It is almost as if the speaker has become objectified and delimited by this "haven": she is simply one more feature amongst the "dried grasses" and "sisal carpets". While the description of the flat seems to contradict the contention that it "supplies no information", the speaker's statement is true in one important respect: since "work can only be selfactualizing when it provides motivation for the worker" (WW 223), the housewife's occupation is said to lack "any motivating factor" and has little possibility for growth or self-advancement; thus, she "cannot get any information about herself from the work she does" (WW 223). Realisation of her enslaved predicament does not lead the speaker to educate her daughter any differently; rather, what the reader witnesses is the child's socialisation for motherhood and the self-perpetuation of dominant patriarchal values: 


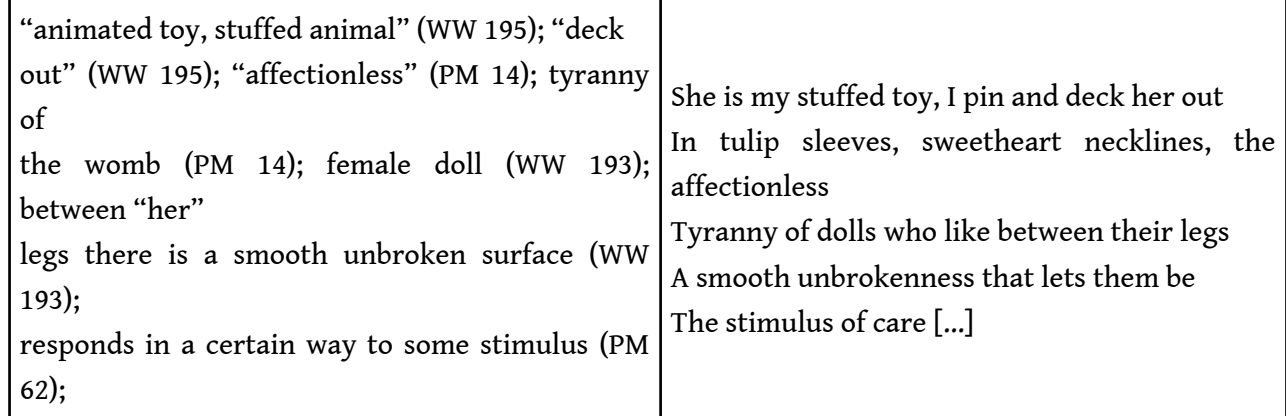

The female child becomes a "stuffed toy", a "doll" with which the mother plays; thus, she too is objectified. The absence of genitalia on the doll is significant: as Oakley comments, when a daughter plays with a doll the message which is transmitted to her "is a denial of biological femaleness, and thus of biological maternity"; hence, what the child learns to value "is not her inherent and quite unchangeable capacity to give birth to children, but the multitude of servicing activities she must perform for them" (WW 193). Conduct books and doll literature portray dolls as useful vehicles in feminine socialisation; in other words, they are used to educate a girl's maternal instinct. However, in the poem it is the mother who plays with the doll (her child). This scenario suggests more than simply the infantalisation of the mother. Since the doll is a selfrepresentational toy which is used to shape and normalise the female subject, to inculcate in her the "conservative patriarchal ideals of female domesticity" ${ }^{23}$ ", one can see that the mother is not only enslaved by "the tyranny of the womb" (her biological condition), but also by "a new, equally implacable Fact of Nature: her child's need for her uninterrupted, undivided and devoted attention" (PM 14). The prevailing Maternal Deprivation Theory argues that the withdrawal of a mother's constant support and attention will lead to an "affectionless" child (one lacking in "normal" values; an asocial monster). Hence, the female subject in this poem is in "bondage" not only to "homemaking" but also to the care of her child.

In her influential monograph entitled On Motherhood, the poet Adrienne Rich argues that " $t]$ he image of the mother in the home, however unrealistic, has haunted and reproached the lives of wage-earning mothers" and that it has created a "dangerous archetype", one which defines the mother as a "source of angelic love and forgiveness in a world increasingly ruthless and impersonal ${ }^{24 "}$ ". Mothers who work are made to feel guilty for not devoting all of their time to the care of their offspring. As an institution, motherhood is viewed by Rich as restricting a woman's potential (in all areas). In an early poem entitled "The Moon Mother", McGuckian uses Rich's text as a source to reflect these views ${ }^{25}$ :

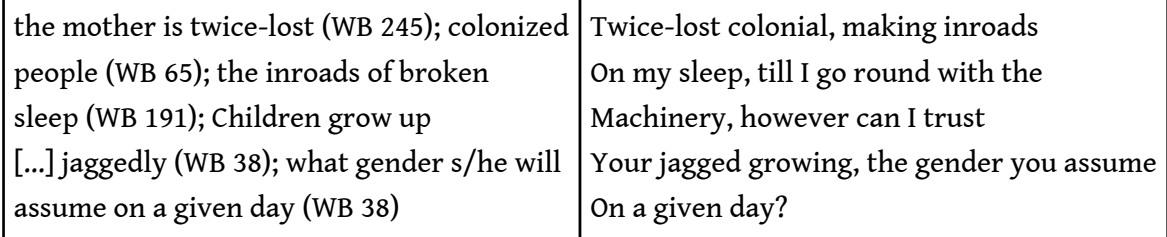


Mothers were not restricted by the institution of marriage; they 'belonged' to themselves and enjoyed great freedom (WB 107). McGuckian's speaker views herself as a colonial subject, twice-lost because she is bound in severance to both husband and child. (One can also read the opening sentence as depicting the child as 'colonial' as s/ he is now part of the patriarchal machine.) The text registers the speaker's anxiety and sheer exhaustion at being the primary care-giver. The mother is bound to the incessant and changing needs of the child. As Rich states, children develop "not in a smooth ascending curve, but jaggedly, their needs inconstant as weather" and "cultural 'norms' are powerless to decide, in a child of eight or ten, what gender s/he will assume on a given day" (WB 38). The speaker's identity is almost effaced: the "I" must "go round with the / Machine" and she is powerless to alter her circumstances.

In a much later poem, "The Doll Funeral”, one written at the time of her own mother's death, McGuckian returns to the "doll" motif and the mechanical model of selfhood, the one now being used as an image for the other. In the final three stanzas, the poet borrows from Miriam Formanek-Brunell's Made to Play House to depict the mother as an automaton, a mechanical doll who is unreflecting in character and repetitive in action $^{26}$

\begin{tabular}{|c|c|}
\hline $\begin{array}{l}\text { A two-piece calico doll (MP77); Clockwork "creeping" } \\
\text { dolls } \\
\text { Crawled by means of two large producting gears (Mp41); } \\
\text { Indestructible dolls (MP79); "so heavy that she was } \\
\text { moved } \\
\text { About on roller" }\end{array}$ & $\begin{array}{l}\text { My two-piece calico, clockwork, } \\
\text { crepping } \\
\text { Doll, so indestructible, so heavy she was } \\
\text { Moved about on rollers } \\
\text { With large, producting gears, }\end{array}$ \\
\hline $\begin{array}{l}\text { "My talking doll [...] was as nearly perfect as machinary } \\
\text { can } \\
\text { be"(MP41); enigmatic [...] mute, vain and delicate } \\
\text { (MP23); } \\
\text { voices were too faint to be heard (MP 58); }\end{array}$ & $\begin{array}{l}\text { My talking doll nearly as perfect } \\
\text { As machinery could be, enigmatic, } \\
\text { Vain, mute and delicate, with voice } \\
\text { Too faint to be heard }\end{array}$ \\
\hline $\begin{array}{l}\text { When sheet music inside the doll body stuck (MP 59); } \\
\text { "two opposite faces" (MP41); A moveable lower lip } \\
\text { (MP41); } \\
\text { "buzzing like an entrapped bee"(MP 59) }\end{array}$ & $\begin{array}{l}\text { When the sheet music inside } \\
\text { Her doll head with two opposite faces } \\
\text { And movable lower lip, stuck, } \\
\text { Buzzing an entrapped bee. }\end{array}$ \\
\hline
\end{tabular}

Selfhood is here effaced: the mother lacks both agency and voice. (Although the doll can talk, its voice is "too feint to be heard".) McGuckian's invocation of the mechanized female subject has its roots in eighteenth-century novels and conduct books in which the machine often "works as the standard against which female character is not only compared and measured, but self-created ${ }^{27}$ ". In such works, as in the poem, the woman is presented as essentially a male construct: fragile, unthinking and utterly compliant. Crucially, the type of doll figured in "The Doll Funeral" was devised by men. As Formanek-Brunell states, businessmen who became doll manufacturers in the late nineteenth-century conceived of the doll as "an autonomous object"; striving for 
realism, they gave it movement and voice, thereby removing "the doll they created from the child's imagination and control" (MP 37). In one respect this had a positive outcome in that the children tended to reject the creation (thus circumventing the socialising process). However, in McGuckian's poem the mechanical doll functions as an image of the mother: she is a truly frightening figure, a creeping monstrous (m)other. Where she once employed caustic irony, now she deploys full-blown Gothic horror in order to critique the male conception of motherhood.

In conclusion, far from being inimical to feminism, McGuckian's poetry, with its historical gaze and intertextual negotiation with past concepts of 'mothering' and 'housewifery', presents a scathing critique of patriarchy. Rather than featuring what Lorenzo-Modia and Fernández-Méndez term a "celebration of motherhood and the maternal body ${ }^{28 "}$, McGuckian's work is alive to the ways in which the female subject is constructed and curtailed by masculinist ideology. The intertextual approach adopted in this article has sought to provide a clear insight into the rationale behind her selections of texts and serve to foreground her feminist credentials: the sources are chosen to learn about the choices made by her female exemplars, and to comment on, or critique, the societal conventions under which they were forced to live.

\section{NOTES}

1. María Jesús Lorenzo-Modia and Cristina Fernández-Méndez, “'Longer and Longer Sentences Prove Me Wholly Female': Medbh McGuckian and Feminism(s)", Writing Bonds: Irish and Galician Contemporary Women Poets, Manuela Palacios and Laura Lojo (eds.) Oxford, Peter Lang, 2009, p. 53.

2. Anne Fogarty, “'A Noise of Myth': Speaking (as) Woman in the Poetry of Eavan Boland and Medbh McGuckian", Paragraph 17.1, March 1994, p. 94.

3. See Guinn Batten, “'The More with Which We Are Connected': The Muse of the Minus in the Poetry of McGuckian and Kinsella", Gender and Sexuality in Modern Ireland, Anthony Bradley and Maryann Gialanella Valiulis, (eds.), Massachusetts, University of Massachusetts Press, 1997, p. 212-244; Sarah Fulford, Gendered Spaces in Contemporary Irish Poetry, Oxford, Peter Lang, 2002, p. 171-197; Moynagh Sullivan, "The In-formal Poetics of Medbh McGuckian", Nordic Irish Studies 3.1, 2004, p. 75-92; Erin C. Mitchell, "Slippage at the Threshold: Postmodern Hospitality in Medbh McGuckian's Poetry", Literature Interpretation Theory 17.2, 2006, p. 137-155.

4. Clair Wills, Improprieties: Politics and Sexuality in Northern Irish Poetry, Oxford, Clarendon Press, 1993, p. 160.

5. Medbh McGuckian, “An Interview with Medbh McGuckian", interview by Susan Shaw Sailer, Michigan Quarterly 32.1, 1993, p. 121.

6. McGuckian, "Surfacing: An Interview with Medbh McGuckian", interview by Kimberly S. Bohman, Irish Review 16, 1994, p. 103.

7. Ibid. 
8. Lorenzo-Modia and Fernández-Méndez, op. cit., p. 53.

9. McGuckian, op. cit., p. 96.

10. Rachel Blau DuPlessis, The Pink Guitar: Writing as Feminist Practice, New York, Routledge, 1990, p. 169.

11. McGuckian, “The Character of the Dug Explained", Eureka Street (June, 2009), [http:// www.eurekastreet.com.au/article.aspx?aeid=14131]. Accessed 3 November 2011. The source text - Will Pritchard, Outward Appearances: The Female Exterior in Restoration London (Lewisburg, Bucknell University Press, 2008) - is referred to as "OA".

12. Peter Stallybrass, "Patriarchal Territories: The Body Enclosed", Rewriting the Renaissance: The Discourses of Sexual Difference in Early Modern Europe, Margaret W. Ferguson, Maureen Quilligan and Nancy J. Vickers (eds.), Chicago, The University of Chicago Press, 1986, p. 126.

13. Jonathan Sawday, The Body Emblazoned: Dissection and the Human Body in Renaissance Culture, London, Routledge, 1995, p. 1.

14. Ibid., p. 2.

15. Ibid., p. 10.

16. Katharine Park, Secrets of Women: Gender, Generation, and the Origins of Human Dissection, New York, Zone Books, 2006, p. 180-181.

17. Stallybrass, p. 127.

18. McGuckian, “The Good Wife Taught her Daughter”, The Currach Requires No Harbours, Oldcastle, Gallery Press, 2006, p. 31-32. Extracts from McGuckian's poem are cited on the right and quotations from the source text - Sarah Salih, "At Home; out of the House", The Cambridge Companion to Medieval Women's Writing, Carolyn Dinshaw and David Wallace (eds.), Cambridge, CUP, 2003, p. 124-140 - are cited on the left, marked "MW". Only one quotation in the poem is from an earlier essay in the Cambridge Companion (Ruth Evans's “Virginities”, p. 21-39).

19. Barbara A. Hanawalt, "Medieval English Women in Rural and Urban Domestic Space", Dumbarton Oak Papers 52, 1998, p. 22.

20. Stallybrass, op. cit., p. 127.

21. McGuckian, "The Good Housewife”, My Love Has Fared Inland, Oldcastle, Meath, 2008, p. 64-65. Extracts from the poem are cited on the right and quotations from the source text - Mary Rogers and Paola Tinagli (eds.), Women in Italy, 1350-1650: Ideals and Realities, Manchester, Manchester University Press, 2005 - are cited on the left and marked "WI".

22. McGuckian, untitled, McGuckian Papers, MS 770, Special Collections, Robert W. Woodruff Library, Emory University, Box 29, folder 5. The poem is cited on the right. Quotations from the source texts - Anna Oakley, Woman's Work: The Housewife, Past and Present, New York, Vintage Books, 1976 and Patricia Morgan, Child Care: Sense and Fable, London, Temple Smith, 1975 - are cited on the right as "WW" and "CC", respectively.

23. Lenore Wright, "The Wonder of Barbie: Popular Culture and the Making of Female Identity", Essays in Philosophy 4.1, 2003, electronic publication - [ http:// commons.pacificu.edu/eip/vol4/iss1/] - consulted 9 November 2011.

24. Adrienne Rich, of Woman Born: Motherhood as Experience and Institution, London, Virago, [1977] 1986, p. 52. 
25. McGuckian, “The Moon Mother”, The Female Line: Northern Irish Women Writers, Ruth Hooley (ed.), Belfast, Northern Ireland Women's Rights Movement, 1985, p. 76. An extract from the poem is cited on the left and quotations from the source are cited on the left, marked "WB".

26. McGuckian, "The Doll Funeral", Blackbox Manifold 4, [ http:// www.manifold.group.shef.ac.uk/issue4/MedbhMcGuckian.html] - consulted 9 November 2011. The poem is cited on the right and the source text - Miriam Formanek-Brunell, Made to Play House: Dolls and the Commercialization of American Girlhood, 1830-1930, Baltimore, The John Hopkins University Press, 1993 - is cited on the left, marked “MP”.

27. Julie Park, "Pains and Pleasures of the Automaton: Frances Burney's Mechanics of Coming Out", Eighteenth-Century Studies, 40.1 Fall, 2006, p. 25.

28. Lorenzo-Modia and Fernández-Méndez, op. cit. p. 49.

\section{ABSTRACTS}

This article argues that Medbh McGuckian's oeuvre is profoundly concerned with matters of female identity in ways that mark it out as feminist. Her historical gaze lays bare the essentialist, gendered rhetoric used within patriarchal culture which renders women as marginal, submissive and disempowered. In poems which borrow from texts as diverse as source books on women's culture in Renaissance Italy and sociological studies of women's housework, McGuckian investigates masculinist ideologies that have controlled and defined women's bodies and behaviour throughout the ages.

Cet article soutient que l'œuvre de Medbh McGuckian témoigne d'un profond engagement féministe dans son traitement de l'identité de la femme. Le regard historique qu'elle porte dénonce la rhétorique essentialiste et genrée employée dans la culture patriarcale qui présente la femme comme figure marginale, soumise et impuissante. Dans des poèmes qui empruntent à des textes aussi variés que des livres sur la culture des femmes en Italie pendant la Renaissance et des études sociologiques sur les femmes et le travail qu'elles exercent au foyer, McGuckian explore les idéologies masculinistes qui ont contrôlé et défini le corps de la femme et son comportement depuis des siècles.

\section{INDEX}

Mots-clés: poésie, féminisme et post-féminisme, femmes, corps, femmes et féminité Keywords: poetry, feminism and post-feminism, women, women and femininity, body 
AUTHOR

SHANE ALCOBIA-MURPHY

University of Aberdeen 